\title{
p53 protein expression in conjunctival squamous cell carcinomas of domestic animals
}

\author{
Giuseppe Sironi, ${ }^{*}$ Pietro Riccaboni, ${ }^{*}$ Luca Mertel, $\dagger$ Giorgio Cammarata, ${ }^{*}$ and Dennis E. Brooksł \\ *Istituto di Anatomia Patologica Veterinaria e Patologia Aviare, Università degli Studi di Milano, Italia, †Istituto di Clinica Chirurgica Veterinaria, Università \\ degli Studi di Milano, Italia, $\ddagger$ Departments of Large and Small Animal Clinical Sciences, University of Florida, Gainesville, Florida
}

\author{
Address communications to: \\ G. Sironi \\ Instituto di Anatomie Patalogica \\ Veterinerie and Patalogica Aviare \\ Via Celorie 10 \\ 20133 Milan \\ Italy \\ Fax: + 390270600112 \\ e-mail: Giuseppe.Sironi@unimi.it
}

\begin{abstract}
The expression of $\mathrm{p} 53$ protein was investigated in eight formalin-fixed, paraffin-embedded conjunctival squamous cell carcinomas of five horses and one cow, dog and cat each by an immunohistochemical procedure in order to evaluate protein overexpression. Anti-human p53 protein mouse monoclonal antibodies known to be cross-reactive with $\mathrm{p} 53$ protein of the animal species examined were used. Positive p53 nuclear immunostaining was detected in five equine, one bovine and one feline cases. Conversely, no p53 immunostaining was found in the only canine case examined. These results demonstrate a frequent p53 overexpression in conjunctival squamous cell carcinoma that could be related to UVinduced mutations of the p53 tumor suppressor gene.
\end{abstract}

Key Words: cat, cattle, conjunctival squamous cell carcinoma, dog, horse, p53 protein

\section{INTRODUCTION}

Conjunctival squamous cell carcinoma is probably the most important primary ocular neoplasm of domestic animals. It arises from the conjunctival epithelium of the limbus, third eyelid or eyelid and it may develop through pretumoral dysplastic lesions, to in situ carcinoma and, ultimately, to invasive carcinoma. It is most commonly seen in bovine and equine species but it has also been reported in the cat and, less frequently, in the dog. ${ }^{1}$

In cattle, the role of genetic and viral factors has been suggested. ${ }^{2}$ However, there is strong evidence that in both cows and cats the prevalence of squamous cell carcinoma is related to sunlight overexposure. ${ }^{1}$ In humans, squamous cell carcinoma of the conjunctiva is a rare tumor with a multifactorial etiology, but exposure to solar UV radiation is considered a major cause of its development. ${ }^{3}$

In recent years, many studies suggested that mutations of the $\mathrm{p} 53$ tumor suppressor gene are involved in the development of human sunlight-related skin cancers, namely squamous cell carcinoma and basal cell carcinoma, and of UVB-induced squamous cell carcinomas of mouse. ${ }^{4}$ Wildtype 553 protein acts as a transcription factor regulating the cell cycle. In response to DNA damage, p53 protein levels temporarily increase resulting in either a delay in progress through the cell cycle to permit repair processes ${ }^{5}$ or the induction of apoptosis. ${ }^{6}$ Thus, p53 monitors the integrity and stability of the genome and minimizes the mutations which arise from exposure to DNA-damaging agents. However, the p53 gene itself can be altered; the consequence is a loss of its regulatory properties which allow cells with DNA damage to replicate with possible selection of malignant clones. Typically, in human cancer, one allele of p 53 is rearranged or deleted such that there is no expression of protein and the remaining allele sustains a missense mutation. This results in expression of a mutant $\mathrm{p} 53$ protein in the absence of any wildtype $\mathrm{p} 53$. Moreover, in some cases in which the wild-type allele is maintained, mutant $\mathrm{p} 53$ protein appears to act in a dominant negative fashion entering into oligomeric complexes with wild-type $\mathrm{p} 53$ and blocking its ability to function. ${ }^{7}$ In addition to molecular-genetic events, p53 function can also be lost by interaction with several cellular or viral proteins. ${ }^{7}$ These protein interactions can either stabilize wild-type p53 protein or accelerate its degradation, resulting in loss of p53 function and uncontrolled cell growth. Wild-type p53 has a short half-life and normal cellular levels are too low to be immunohistochemically detected. ${ }^{8}$ Missense mutations, the most frequent p53 abnormality, often increase the half-life and nuclear concentration of the protein, allowing its immunohistochemical detection. ${ }^{9}$ Overexpression of the protein is therefore considered an indicator of mutation although the existence of other molecular alterations, that can also account for increased stability of $\mathrm{p} 53$ in the absence of mutations, suggests a more careful evaluation. ${ }^{10}$

Mutations of the p53 gene have been recently detected in domestic animals. ${ }^{11-15}$ Moreover, aberrant expression of $\mathrm{p} 53$ protein has been described in squamous cell carcinomas of cattle, horses, cats and dogs. ${ }^{16-18}$

This study was undertaken to assess, immunohistochemically, the expression of p53 protein in some conjunctival 
squamous cell carcinomas of various domestic animal species with the aim of investigating the role of $\mathrm{p} 53$ dysfunction in the development of conjunctival squamous cell carcinoma.

\section{MATERIALS AND METHODS}

A total of eight conjunctival squamous cell carcinomas (five equine, one bovine, one canine and one feline cases) were available for examination. The specimens were fixed in $10 \%$ buffered formalin and embedded in paraffin wax. Four $\mu \mathrm{m}$ sections were routinely stained with hematoxylin and eosin and evaluated by light microscopy to confirm the diagnosis. Serial sections were dewaxed in a graded xylol/alcohol series, rehydrated in distilled water and placed in a plastic jar filled with a 6-M urea solution. The jars were irradiated in a household microwave oven (Candy M1000 X; Candy S.r.l., Monza, Italy) twice for $5 \mathrm{~min}$ each at $75 \%$ power and were allowed to cool for a minimum of $15 \mathrm{~min} .{ }^{19}$ Then the sections were processed for indirect immunohistochemistry with a standard avidin-biotin technique (ABC Vectastain Elite kit; Vector Laboratories, Burlingame CA, USA). Briefly, the sections were washed twice in distilled water and in Tris buffer saline (TBS), incubated at room temperature with 1:75 normal horse serum, for $20 \mathrm{~min}$, then incubated overnight at $4{ }^{\circ} \mathrm{C}$ with the primary antibodies listed in Table 1. One or more different primary antibodies were used according to the data about species crossreactivity reported in Table 1 . Following the incubation with primary antibodies, the slides were rinsed in TBS and incubated for $30 \mathrm{~min}$ with a biotinylated antibody 1:200 (Vector Laboratories, Burlingame, CA) and then with avidin-biotin peroxidase compex (ABC Elite, Vector Laboratories). Aminoethylcarbazole (AEC, Sigma Chemical Co, St. Louis, MO, USA) was used as chromogen and Mayer's hematoxylin as counterstain. As a positive control of the immunolabeling, a human breast carcinoma known to overexpress p53 was used while normal tissues (conjunctival epithelium or eyelid skin) adjoining the neoplastic tissues were utilized as a negative control. Moreover, primary antibodies validation was performed in preliminary tests in which normal tissues of each species (horse, cattle, dog and cat) from various sites and organs (skin, intestine, spleen, lymph nodes, liver, kidney and heart) were immunohistochemically examined to verify the absence of unspecific reactions of the anti-p53 antibodies.
The degree of the immunostaining was graded as follows: $(+)<10 \%$ nuclei staining intensely; $(++) 10-50 \%$ nuclei staining intensely; $(+++)>50 \%$ nuclei staining intensely.

\section{RESULTS}

Expression of p53 protein was detected in almost all the neoplastic cells of positive control while it was absent in the normal tissues of the samples examined. Table 2 summarizes the results of the immunohistochemical assay of the eight conjunctival squamous cell carcinomas examined for p 53 staining. Nuclear p53 immunolabeling was found in neoplastic cells of five equine, one bovine and one feline cases. No immunostaining was observed in neoplastic cells of the canine sample. Expression of p53 protein was not detected in normal tissues. In cases tested with different primary antibodies, a constant weaker reactivity of PAb 240 in comparison with DO1 and DO12 antibodies was found. In positive cases, the proportion of positive nuclei was estimated from $35 \%$ to $90 \%$.

In moderately differentiated squamous cell carcinomas reactivity involved most of the tumor cells' nuclei (Fig. 1), while in well-differentiated carcinomas positive staining was mainly restricted to proliferating basal-like cells at the periphery of the tumoral nests (Fig. 2). In one of the equine cases, strong and extensive immunoreactivity also reached basal and suprabasal cells of a tract of dysplastic epithelium and completely disappeared, with a clear boundary, only in the adjoining normal epithelium (Fig. 3a,b).

Table 2 Results of the immunohistochemical analysis for $\mathrm{p} 53$ protein

\begin{tabular}{lllll}
\hline & & \multicolumn{2}{l}{ Degree of immunostaining } \\
\cline { 3 - 5 } Case & Species & PAb 240 & DO1 & DO12 \\
\hline 1 & Horse & +++ & +++ & +++ \\
2 & Horse & ++ & ++ & ++ \\
3 & Horse & +++ & +++ & +++ \\
4 & Horse & +++ & +++ & +++ \\
5 & Horse & +++ & +++ & +++ \\
6 & Cattle & +++ & +++ & n.d. \\
7 & Cat & +++ & +++ & n.d. \\
8 & Dog & - & n.d. & n.d. \\
\hline
\end{tabular}

$(-)$ negative; $(+)<10 \%$ nuclei staining; $(++) 10-50 \%$ nuclei staining $(+++)>50 \%$ nuclei staining; n.d. analysis not performed.

Table 1 List of the antibodies used

\begin{tabular}{llllll}
\hline Primary antibody & Ig subclass & Binding site (aa) ${ }^{*}$ & Specie cross-reactivity $\dagger$ & Dilution & Source \\
\hline DO 1 & IgG2a & $20-25$ & Cat, horse, bovine ${ }^{17,18,20}$ & $1: 2000$ & Oncogene Sci. \\
DO 12 & IgG1 & $256-270$ & Horse ${ }^{21,22}$ & $1: 200$ & Lane D.P. \\
PAb 240 & IgG1 & $213-217$ & Dog, cat, horse, bovine ${ }^{16}$ & $1: 400$ & Oncogene Sci. \\
Normal mouse serum & $=$ & $=$ & $=$ & $1: 1000$ & Dakopatts \\
\hline
\end{tabular}

*Epitope localization is referred to the amino acid sequence of human p53.

$\dagger$ Data about species cross-reactivity are reported from previously published studies ${ }^{16-18,20}$ or obtained by comparison of published p 53 protein sequences. $^{20,21}$ 


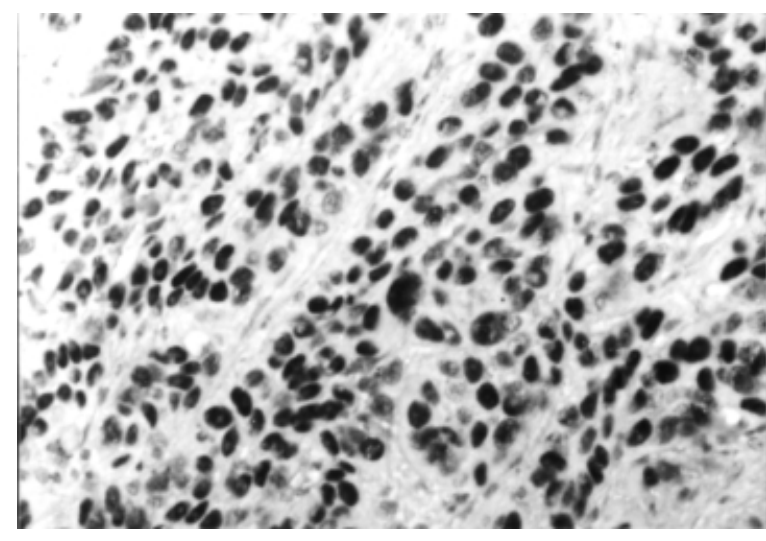

Figure 1. Conjunctival squamous cell carcinoma of a cat displaying extensive immunostaining of neoplastic cell nuclei. ABC-peroxidase method, PAb 240 antibody, Mayer's hematoxylin counterstain, $\times 460$.

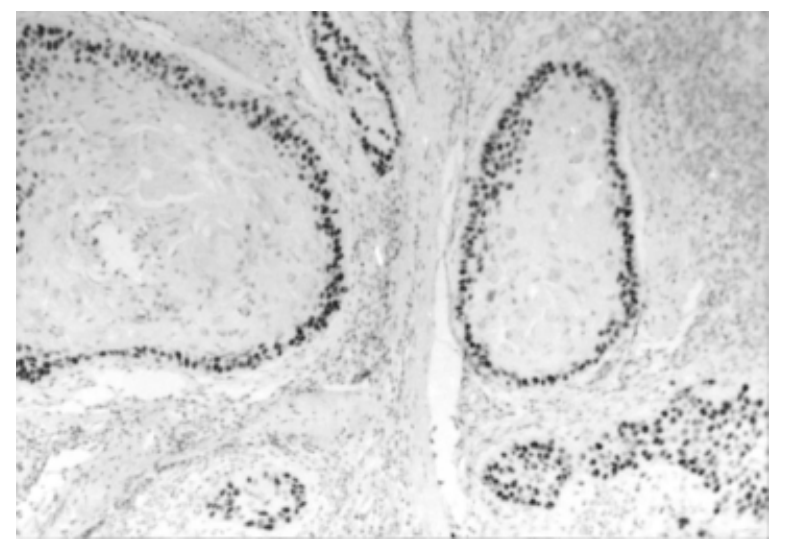

Figure 2. Overexpression of $\mathrm{p} 53$ protein is noted in nuclei of peripheral tumor cells of a conjunctival squamous cell carcinoma of a horse. ABCperoxidase complex method, DO1 antibody, Mayer's hematoxylin counterstain, $\times 180$.

\section{DISCUSSION}

The present data show that abnormal p53 accumulation is frequently present in conjunctival squamous cell carcinomas of domestic animals and suggest that $\mathrm{p} 53$ protein dysfunction could be involved in carcinogenesis of ocular squamous cell carcinoma. This is in accordance with the results previously reported by Teifke and Löhr, ${ }^{16}$ describing aberrant p53 expression in squamous cell carcinomas of cattle, horses, cats and dogs and showing a high rate of p53 positive cases in equine and bovine tumors with ocular location. Similarly, a high rate of $\mathrm{p} 53$-positive cases has been recently reported in human pterygia and limbal tumors ${ }^{23-25}$ and it has been suggested that the finding of increased nuclear p53 in the limbal cells of all pterygia, limbal tumors and most pingueculae indicates the probable existence of $\mathrm{p} 53$ mutations which could be caused by UV radiation. However, the precise implication of p53 in the genesis of conjunctival dysplastic and neoplastic lesions both in domestic animals and in humans has yet to be elucidated. (a)

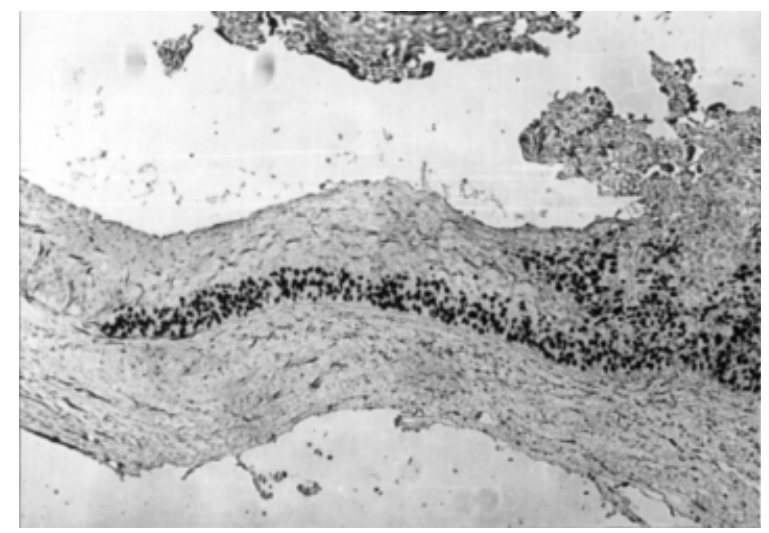

(b)

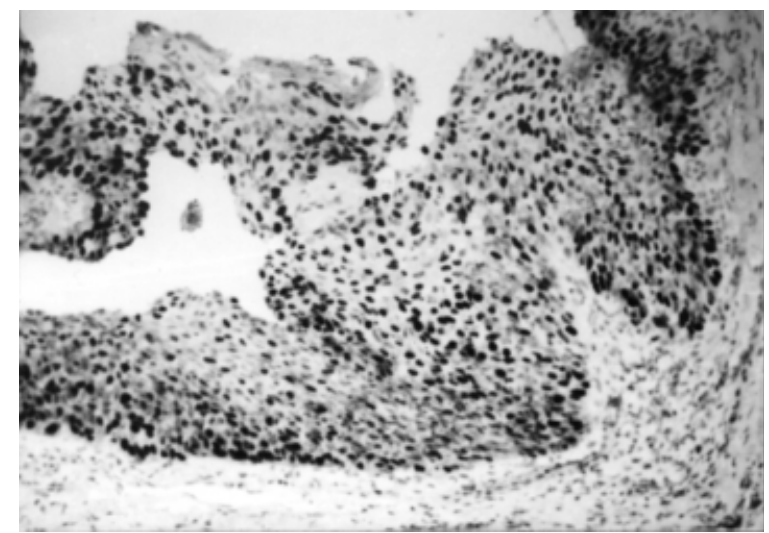

Figure 3. (a) Immunohistochemical staining for $\mathrm{p} 53$ protein in a conjunctival squamous cell carcinoma of a horse. Strong and extensive p53 nuclear immunoreactivity is seen in the basal and suprabasal cells of a tract of dysplastic epithelium, $\times 180$. (b) Extensive immunolabeling is present in neoplastic cells of the adjoining in situ squamous cell carcinoma. ABC-peroxidase complex method, DO1 antibody, Mayer's hematoxylin counterstain, $\times 220$.

It is generally assumed that the immunohistochemical demonstration of p53, particularly by PAb 240 and DO12 antibodies, indicates the presence of a mutant protein. However, PAb 240 and DO12 can be considered specific for mutant $\mathrm{p} 53$ protein only under testing conditions which are not denaturing, ${ }^{21,26}$ and cases of $\mathrm{p} 53$ protein accumulation with no evidence of genetic alteration have been described in a wide range of malignant tumors. ${ }^{10}$ Several other mechanisms may account for $\mathrm{p} 53$ overexpression which may result either from a stabilization of the protein via interaction with viral and cellular oncoproteins or an alteration of the p53 degradative pathway. ${ }^{27}$ In many studies on $\mathrm{p} 53$ expression in neoplastic diseases, more than $10 \%$ or $20 \%$ positive cells has been regarded as the cut-off for $\mathrm{p} 53$ positivity indicating the presence of mutation. ${ }^{28-30}$ On the other hand, $\mathrm{p} 53$ protein expression in a small fraction of neoplastic cells is probably poorly related with the accumulation of a mutant $\mathrm{p} 53$ protein. $^{31,32}$ In our cases the high rate of $\mathrm{p} 53$ expression in tumor cells is therefore suggestive of $\mathrm{p} 53$ mutation.

At present, little is known regarding p53 mutation in squamous cell carcinomas of domestic animals. Pazzi et al..$^{22}$ 
described p53 point mutations in two of eight cutaneous or mucocutaneous squamous cell carcinomas of horses. In both cases (one of the eyelid and the other located in the vulva) point mutations were C-to- $\mathrm{T}$ transitions, a type of mutation considered a typical 'signature' of the UV radiationinduced mutations. ${ }^{4}$

Conjunctival squamous cell carcinoma, particularly in cattle, can develop through multiple stages including metaplasia, followed by dysplasia, carcinoma in situ and invasive carcinoma. ${ }^{1,2}$ In one of the equine samples containing also normal and dysplastic conjunctiva, positive nuclei were confined to the basal and suprabasal cells within lowgrade dysplastic epithelium, increased in the well-differentiated neoplastic areas and involved all the tumor cells in the more undifferentiated areas. Such a finding suggests that $\mathrm{p} 53$ protein overexpression could be an early event in the progression from dysplasia to squamous cell carcinoma. Evidence of p53 mutation and overexpression in the early stage of carcinogenesis has been also found in human cutaneous squamous cell carcinomas. ${ }^{33,34}$

In conclusion, further studies on a larger number of samples are necessary to evaluate the prevalence of p53 overexpression in conjunctival squamous cell carcinomas of domestic animals. Moreover, detailed molecular analysis of $\mathrm{p} 53$ should be performed to evaluate the presence of p53 mutations with a typical UV-induction pattern in these cases.

\section{ACKNOWLEDGMENTS}

The research was supported by grants from the Ministero della Ricerca Scientifica e Tecnologica (MURST), cofinanziamento 1997.

The authors sincerely thank Dr D. P. Lane, Cancer Research Campaign Laboratories, Department of Biochemistry, University of Dundee, UK, for the generous gift of the DO 12 monoclonal antibody.

\section{REFERENCES}

1 Wilcock BP. The eye and ear. In: Pathology of Domestic Animals 4th edn (eds Jubb KVF, Kennedy PC, Palmer N) Academic Press, San Diego, 1993; 441-529.

2 Miller TR, Gelatt KN. Food animal ophthalmology. In: Veterinary Ophthalmology 2nd edn (ed. Gelatt KN). Lea and Febiger, Philadelphia, 1991; 611-655.

3 Newton R. A review of the aetiology of squamous cell carcinoma of the conjunctiva. British fournal of Cancer 1996; 74: 1511-1513.

4 Brash DE, Ziegler A, Jonason AS, Simon JA, Kunala S, Leffell DJ. Sunlight and sunburn in human skin cancer: p53, apoptosis and tumor promotion. Fournal of Investigative Dermatology, Symposium Proceedings 1996; 1: 136-142.

5 Kastan MB, Onyekwere O, Sidransky D, Vogelstein B, Craig RW. Participation of $\mathrm{p} 53$ protein in the cellular response to DNA damage. Cancer Research 1991; 51: 6304-6311.

6 Lane DP. p53, guardian of the genome. Nature 1992; 358: 15-16.

7 Levine AJ, Perry ME, Chang A, Silver A, Dittmer D, Wu M, Welsh D. The 1993 Walter Hubert Lecture: The role of the p53 tumour- suppressor gene in tumorigenesis. British fournal of Cancer 1994; 69: 409-416.

8 Iggo R, Gatter K, Bartek J, Lane D, Harris AL. Increased expression of mutant forms of p53 oncogene in primary lung cancer. Lancet 1990; 335: 675-679.

9 Lane DP. The regulation of p53 function: Steiner award lecture. International Fournal of Cancer 1994; 57: 623-627.

10 Hall PA, Lane DP. p53 in tumour pathology: can we trust immunocytochemistry? - revisited. Fournal of Pathology 1994; 172: 1-4.

11 Dequiedt F, Kettmann R, Burny A, Willems L. Mutations in the p53 tumor-suppressor gene are frequently associated with bovine leukemia virus-induced leukemogenesis in cattle but not in sheep. Virology 1995; 209: 676-683.

12 Devilee P, Van Leeuver IS, Vaesler A, Rutteman GR, Cornelisse CJ. The canine p53 gene is subjected to somatic mutation in thyroid gland. Anticancer Research 1994; 14: 2039-2046.

13 Mayr B, Heczko U, Schellander K, Schleger W, Reifinger M. Sequence of an exon of the feline p53 gene. Mutation in a lymphosarcoma. British Veterinary fournal 1993; 149: 387-390.

14 Mayr B, Schellander K, Schleger W, Reifinger M. Sequence of an exon of the canine p53 gene. Mutation in a papilloma. British Veterinary fournal 1994; 150: 81-84.

15 Mayr B, Schaffner G, Kurzbauer R, Schneider A, Reifinger M, Loupal G. Mutation in tumour suppressor gene p53 in two feline fibrosarcomas. British Veterinary fournal 1995; 151: 707-713.

16 Teifke JP, Löhr CV. Immunohistochemical detection of p53 overexpression in paraffin wax-embedded squamous cell carcinomas of cattle, horses, cats and dogs. Fournal of Comparative Pathology 1996; 114: 205-210.

17 Johnston HM, Thompson H, Pirie HM. p53 immunohistochemistry in domestic animal tumours. European Fournal of Veterinary Pathology 1996; 2: 135-140.

18 Sironi G. Alterata espressione del tumor suppressor gene p53 in neoplasie di alcune specie domestiche. Atti della $\mathrm{II}^{\mathrm{a}}$ Conferenza nazionale su: Stato dell'arte delle ricerche italiane nel settore delle biotecnologie applicate alle scienze veterinarie e zootecniche. Milano, 22 Aprile 1994. Quaderni della Fondazione Iniziative Zooprofilattiche e Zootecniche 1995; 37: 125-135.

19 Cattoretti G, Pileri G, Parravicini C et al. Antigen unmasking on formalin fixed, paraffin embedded tissue sections. Fournal of Pathology 1993; 171: 83-98.

20 Vojtesek B, Bártek J, Midgley CA, Lane DP. An immunochemical analysis of the human nuclear phosphoprotein p53. Fournal of Immunological Methods 1992; 151: 237-244.

21 Vojtesek B, Dolezalova H, Lauerova L, Svitakova M, Havlis P, Kovarik J, Midgley CA, Lane DP. Conformational changes in p53 analysed using new antibodies to the core DNA binding domain of the protein. Oncogene 1995; 10: 389-393.

22 Pazzi KA, Kraegel SA, Griffey SM, Theon AP, Madewell BR. Analysis of the equine tumor suppressor gene p53 in the normal horse and in eight cutaneous squamous cell carcinomas. Cancer Letters 1996; 107: 125-130.

23 Calzolari A, Mincione F, Messerini L, Parducci V, Giannelli E, Mincione G. p53 protein overexpression in a case of conjunctival micro-invasive carcinoma. European Fournal of Ophthalmology 1994; 4: 184-186.

24 Dushku N, Reid TW. p53 expression in altered limbal basal cells of pingueculae, pterygia, and limbal tumors. Current Eye Research 1997; 16: $1179-1192$

25 Tan DT, Lim AS, Goh HS, Smith DR. Abnormal expression of the p53 tumor suppressor gene in the conjunctiva of patients with pterygium. American fournal of Ophthalmology 1997; 123: 404-405.

26 Gannon JV, Greaves R, Iggo R, Lane DP. Activating mutations in p53 produce a common conformational effect. A monoclonal 
antibody specific for the mutant form. EMBO fournal 1990; 9: $1595-1602$.

27 Blagosklonny MV. Loss of function and p53 protein stabilization. Oncogene 1997; 15: 1889-1893.

28 Gazzeri S, Brambilla E, Caron de Fromentel C, Gouyer V, Moro D, Perron P, Berger F, Brambilla C. p53 genetic abnormalities and myc activation in human lung carcinoma. International fournal of Cancer 1994; 58: 24-32.

29 Taubert H, Würl P, Meye A, Berger D, Thamm B, Neumann K, Hinze R, Schmidt H, Rath FW. Molecular and immunohistochemical p53 status in liposarcoma and malignant fibrous histiocytoma. Identification of seven mutations for soft tissue sarcoma. Cancer 1995; 76: 1187-1196.

30 Sagartz JE, Bodley WL, Gamblin RM, Couto CG, Tierney LA,
Capen CC. p53 tumor suppressor protein overexpression in osteogenic tumors of dogs. Veterinary Pathology 1996; 33: 213-221.

31 Scarpa A, Capelli P, Mukai K, Zamboni G, Oda T, Iacono C, Hirohashi S. Pancreatic adenocarcinomas frequently show p53 gene mutations. American fournal of Pathology 1993; 142: 1534-1543.

32 Dowell SP, Hall PA. The clinical relevance of the p53 tumour suppressor gene. Cytopathology 1994; 5: 144-145.

33 Nelson MA, Einspahr JG, Alberts DS et al. Analysis of the p53 gene in human precancerous actinic keratosis lesions and squamous cancers. Cancer Letters 1994; 85: 23-29.

34 Taguchi M, Watanabe S, Yashima K, Murakami Y, Sekiya T, Ikeda $\mathrm{S}$. Aberrations of the tumor suppressor gene and $\mathrm{p} 53$ protein in solar keratosis in human skin. Fournal of Investigative Dermatology 1994; 103: $500-503$. 